Research article

\title{
Isolation and characterization of lectin from the leaves of Euphorbia tithymaloides (L.)
}

\author{
Aruna A. Jawade, Shubhangi K. Pingle*, Rajani G. Tumane, Anvita S. Sharma, \\ Archana S. Ramteke and Ruchika K. Jain \\ National Institute of Miners’ Health, JNARDDC Campus, Wadi Nagpur-440023, Maharashtra, India \\ *Corresponding Author: pingle.shubhangi@gmail.com \\ [Accepted: 03 December 2016]
}

\begin{abstract}
Lectins or glycoproteins from the leaves of Euphorbia tithymalo were isolated after screening of different flora from Central India. The crude extract of leaves was dialyzed andammonium sulfate precipitation done and followed by dialysis for the purification of lectins. Protein concentration in the purified extract was $10 \mathrm{mg} \cdot \mathrm{ml}^{-1}$ measured by Biuret Method. The purified lectins were able to agglutinate human erythrocytes of ABO blood group system. Agglutination was also visible with animal erythrocytes. Lectin of ET was Galactose/Lactose specific and shows maximum activity at $\mathrm{pH}-7$ and temperature between $40-60^{\circ} \mathrm{C}$. Molecular weight of purified extract of ET was determined by 1D- SDS Polyacrylamide gel electrophoresis which was found to be 70.24, 28.53 and $14.68 \mathrm{kDa}$.
\end{abstract}

Keywords: Agglutination - Blood group - Electrophoresis - Euphorbia - Glycoprotein.

[Cite as: Jawade AA, Pingle SK, Tumane RG, Sharma AS, Ramteke AS \& Jain RK (2016) Isolation and characterization of lectin from the leaves of Euphorbia tithymaloides (L.). Tropical Plant Research 3(3): 634641]

\section{INTRODUCTION}

Lectins are proteins or glycoproteins of non-immune origin which possess the ability to agglutinate erythrocytes or precipitate glycoconjugates by binding to the recognized and specific carbohydrate residue present on cell surface (Ramteke 2009). Lectins are widely distributed in nature and can be found in many plants, animals and microorganisms. Plant lectin contains at least one catalytic domain and has the ability to recognize complex glycoconjugates (Peumans \& Damme 1998). Lectins present in leaves, roots, stems and seeds of plants perform different biological activities and help in secondary metabolism such as defense mechanism. Due to specific binding capabilities, lectins involve in endocytosis, intracellular translocation of glycoproteins, cellular regulation, migration and adhesion, phagocytosis, binding of microorganisms to target tissues, control of morphogenesis, metastasis and many other activities (Sharon \& Lis 2004, Abreu \& Matthew 2006). ABO blood group system with Rhesus factor comprises of distinct determinant and lectins agglutinate with specific type of antigen present on RBCs (Ajit \& Kanjaksha 2016).

Euphorbia tithymaloid (ET) is a perennial succulent spurge. It is native to tropical and sub-tropical North America and Central America. These shrubs are 6 to 8 feet long and 18 to 24 inch wide. ET grows in fertilized sandy soil rich in metal concentration like boron, copper, iron, manganese, molybdenum and zinc. Their leaves are alternate, sessile, glabrous and acuminate in shape. It is a carcinogenic plant thus has the ability to grow in toxic soil very easily and rapidly. Sometimes, ET is also used to remediate soil and can be used as border of garden. Lectins present in this plant have many medicinal use and help in curing many diseases also. It shows anti-inflammatory, anti-bacterial, anti-septic, anti-hemorrhagic, anti-viral, anti-tumor and abortive properties. In this study lectins from the leaves of ET were characterized in terms of their physical, chemical and biological properties.

\section{MATERIALS AND METHODS}

Leaves of ET were collected from Nagpur, Maharashtra in Central India and used as source of lectins. 
Human blood of groups $\mathrm{A} \mathrm{Rh}+, \mathrm{B} \mathrm{Rh}+$ and $\mathrm{O} \mathrm{Rh}+$ were collected from healthy persons. Animal bloods were collected from veterinary hospital of Nagpur, Maharashtra. Ammonium sulfate, sodium chloride, dialysis membrane-50, total protein kit (BioSystem-Reagent and chemicals), different sugars, $\mathrm{pH}$ buffers ( $\mathrm{pH} 2-12$ ), acrylamide, bis-acrylamide, $\beta$-Mercaptoethanol, coomassie brilliant blue, urea, thiourea, DDT, CHAPS, IPG strips, bromophenol blue, glycerol, SDS, TEMED and other chemicals were purchased from Himedia and Serva.

\section{Preparation of crude extract}

Leaves of ET were collected from the road side area of Nagpur, Maharashtra. Leaves were washed 2-3 times with tap water and then with distilled water and soaked in tissue paper. Leaves were homogenized with minimum amount of saline by using mortar and pestle at $4^{\circ} \mathrm{C}$. Homogenized extract was allowed to filter by using muslin cloth. The filtrate was centrifuged at $5000 \mathrm{rpm}$ for 20 minutes. The obtained supernatant was stored at $4^{\circ} \mathrm{C}$ and used for further analysis (Patil \& Despande 2015).

\section{Purification of crude extract}

The crude extract was dialyzed for the separation of proteins and removal of impurity and small moleculesby dialysis membraneinnormal saline at $4^{\circ} \mathrm{C}$. This membrane contains micro pores through which the small molecules easily escaped. Therefore, protein molecules having dimensions significantly greater than the pore diameter are retained inside the dialysis bag. Ammonium sulfate (AS) was used to precipitate lectins from the dialyzed extract by gradualaddition of ASat $4^{\circ} \mathrm{C}$. The precipitation obtained after $0-100 \%$ saturation of AS was centrifuged at 6,000 rpm for 30 minutes. Then, precipitate was dissolved in normal saline and again dialyzed till the solution was free from ammonium sulfate fraction (ASF).

\section{Protein Estimation}

Protein was estimated by using commercially available protein kit.

\section{Preparation of $2 \%$ erythrocytes}

The human blood samples werecollected in heparinized tubes and stored at $4^{\circ} \mathrm{C}$. Erythrocytes were washed 3-4 times with normal saline. Washed RBCs were used for preparation of $2 \%$ erythrocytes solution (Olsen 1944). Similarly, animal bloodswere also preceded as mentioned above. This $2 \%$ erythrocytes solution was used for determination of hemagglutination activity.

\section{Agglutination assay}

Agglutination test of purified extract was done by using 2\% suspension of erythrocytes (Deshpande \& Patil 2003). Hemagglutination activity was determined in 96 wells plate by using serial dilution. Agglutination was observed visually with carpet and button pattern after 5 hrs. Hemagglutination unit (HAU) which represents the titer strength was calculated with the reciprocal of last dilution of agglutination. Specific activity (SA) which is HAU per mg protein was also calculated.

\section{Agglutination inhibition assay}

Agglutination inhibition assay was done by testing the ability of different carbohydrates like disaccharides, pentoses, hexoses, oligosaccharides etc. to inhibit the agglutination (Kurokawa et al. 1976). $100 \mu 1$ of $500 \mathrm{mM}$ sugar solutions were incubated with $100 \mu \mathrm{l}$ lectin for 30 minutes at room temperature. The agglutination in the presence of sugar was examined with $2 \%$ erythrocytes by the above described method. Minimum inhibitory concentration was taken which did not agglutinate the erythrocytes.

\section{pH stability studies}

The $\mathrm{pH}$ dependence of ET leaves lectin was determined by using buffer ranging from $\mathrm{pH} 1-13$. For $\mathrm{pH} 1$ : $0.1 \mathrm{~N} \mathrm{HCl}$, for $\mathrm{pH} 2 \&$ 3: 0. 2M glycine - $\mathrm{HCl}$ buffer, for $\mathrm{pH} 4$ \& 5: 0.2M sodium acetate buffer, for $\mathrm{pH} 6$ \& 7 : $0.2 \mathrm{M}$ sodium phosphate buffer, for $\mathrm{pH}$ 8: $0.2 \mathrm{M}$ Tris $\mathrm{HCl}$ buffer, for $\mathrm{pH} 9: 0.2 \mathrm{M}$ glycine- $\mathrm{NaOH}$ buffer and for $\mathrm{pH} 10 \&$ 13: $0.2 \mathrm{M}$ carbonate-bicarbonate buffers were used. $100 \mu \mathrm{l}$ of lectin was incubated with $100 \mu \mathrm{l}$ of different buffer solutions for 30 minutes at room temperature and then assayed for agglutination with $2 \%$ erythrocytes (Suseelan et al. 1997).

\section{Temperature stability study}

Effect of temperature on the lectins of ET was observed by incubating $100 \mu \mathrm{l}$ of leaves extract at different temperature ranging from $10-100^{\circ} \mathrm{C}$ for 30 minutes. Agglutination test was carried out with $2 \%$ erythrocytes solution. 
SDS polyacrylamide gel electrophoresis (SDS-PAGE)

SDS-PAGE was done to determine the molecular weight of lectins of ET by the method of Weber \& Osborn (1969). A 10\% stacking gel and 5\% running gel was used in SDS-PAGE with a standard marker protein (Aprotinin-6.5kDa, Lyzozyme-14.3 kDa, Soyabean Trypsin Inhibitor-20.1 kDa, Carbonic Anhydrase-29 kDa, Ovalbumin-43 kDa, Bovine Serum Albumin-66 kDa and Phosphorylase b-97.4 kDa). After electrophoresis the gel was stained with $0.2 \%$ coomassie brilliant blue (R250) and then destained in $10 \%$ acetic acid.

\section{Isoelectric focusing}

In 2-D electrophoresis, IPG (Immobilized $\mathrm{pH}$ gradient) strip of $\mathrm{pH}$ ranging 3-10 was used to perform isoelectric focusing of the sample. The strip containing sample were rehydrated using rehydrating buffer $(6 \mathrm{M}$ Urea, 4\% CHAPS, ampholyte, $0.1 \%$ Bromophenol blue) at room temperaturefor $18 \mathrm{hrs}$. 1D was performed according to the standard method after which the strip was treated with equilibration buffer (1.5 M TrisHCl, $6 \mathrm{M}$ Urea, 30\% glycerol, $2 \%$ SDS, $0.01 \%$ Bromophenol blue and $200 \mathrm{mg}$ of dithiothreitol) and with blocking buffer (1.5 M TrisHCl, 6M Urea, 30\% glycerol, 2\% SDS, 0.01\% Bromophenol blue and $250 \mathrm{mg}$ of iodoacetamide). Then 2D SDS-PAGE was allowed to run with $10 \%$ running gel at $15^{\circ} \mathrm{C}$. The spots appeared after $0.2 \%$ Coomassie blue stain was destained by using $10 \%$ acetic acid.

\section{RESULTS}

A total 120 herbs and shrubs from Nagpur District were randomly selected and screened for identification of agglutination activity. The crude extract of 25 plants showed agglutination activity with erythrocytes of different blood groups of human and animals. On the basis of literature survey and information obtained from civilian about medicinal valuesthree plantswere selected for further study. ET was selected as it showed good agglutination activity against blood group system (ABO).

\section{Protein estimation}

Protein content in the dialyzed extract of ET was found to be $10 \mathrm{mg}^{\mathrm{m}} \mathrm{ml}^{-1}$ by using Biuret kit.

\section{Agglutination assay}

Table 1. Agglutination study of lectins of Euphorbia tithymaloides leaves with human and animal erythrocytes.

\begin{tabular}{ll}
\hline Erythrocytes & Agglutination \\
\hline Human 'O' & +++ \\
Human 'B' & ++ \\
Human 'A' & + \\
Cow & + \\
Dog & - \\
Fish & - \\
Hen & - \\
\hline
\end{tabular}

Hemagglutination results in table 1 revealed that human blood group ' $\mathrm{O}$ ' showed strong agglutination as compared to 'A' and 'B' with lectin from the leaves of ET. In figure 1, blood group 'A', 'B' and ' $O$ ' gives carpet pattern till 6,7 and 8 times dilutions respectively and on further dilution button pattern starts appearing which represents no more further precipitation of lectins. Plant lectin has also showed agglutination against cow erythrocyte but no agglutination was found in case of dogs, fish and hen (table 1). On the basis of result it was observed that minimum concentration of lectin was required for agglutination of group ' $\mathrm{O}$ ' erythrocyte and was followed by group 'B' and group 'A'. Hemagglutination unit (HAU) and specific activity (SA) were also calculated and depicted in the table 2.

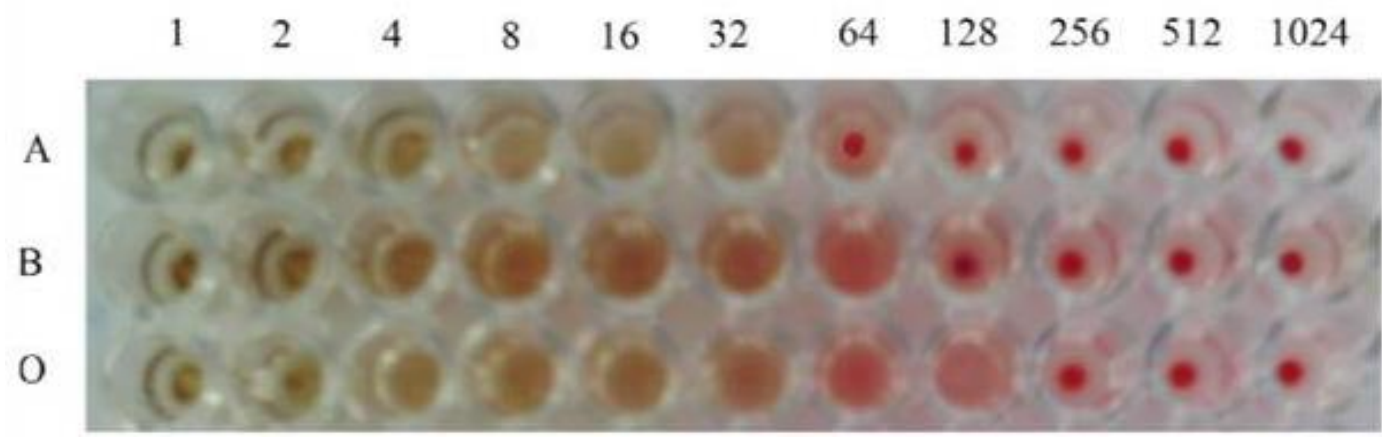

Figure 1. Hemagglutinationtiterwith $\mathrm{ABO}$ blood group. 
Table 2. Protein concentration in leaves of Euphorbia tithymaloides.

\begin{tabular}{|c|c|c|c|c|c|c|c|}
\hline & \multirow{2}{*}{ Protein $\left(\mathbf{m g} \cdot \mathbf{m l}^{-1}\right)$} & \multicolumn{3}{|c|}{ HAU/ml } & \multicolumn{3}{|c|}{$\mathbf{S A}$} \\
\hline & & 'A' & 'B' & 'O' & 'A' & 'B' & ' $\mathbf{O}$ ' \\
\hline Dialyzed extract & 10 & 320 & 640 & 1280 & 32 & 64 & 128 \\
\hline
\end{tabular}

Note: HAU-Hemagglutination Unit, SA-Specific activity.

Agglutination inhibition assay

Agglutination activity of lectin from leaves of ET was inhibited by D-Galactose and Lactose as showed in table 3. Result indicated inhibition of lectin was due to galactose/lactose specific sugars.

Table 3. Inhibition of agglutination with different sugars by lectins of Euphorbia tithymaloides leaves.

\begin{tabular}{lc}
\hline Sugars & $\begin{array}{c}\text { Minimum concentration required to inhibit the } \\
\text { hemagglutination }(\mathbf{m M})\end{array}$ \\
\hline D-Glucose & No inhibition \\
Sucrose & No inhibition \\
Lactose & 500 \\
Sorbitol & No inhibition \\
D-Fructose & No inhibition \\
D-Maltose & No inhibition \\
D-Arabinose & No inhibition \\
D-Galactose & 500 \\
D-Xylose & No inhibition \\
D-Mannose & No inhibition \\
D-Ribose & No inhibition \\
\hline
\end{tabular}

pH stability

According to the result the optimum $\mathrm{pH}$ for maximum agglutination by leaves of ET was found to be neutral ( $\mathrm{pH} 7$ ). The activity varies in $\mathrm{pH}$ ranging from 3 to 11 . Agglutination activity was lost below $\mathrm{pH} 4$ and above $\mathrm{pH}$ 11 as mentioned in figure 2.

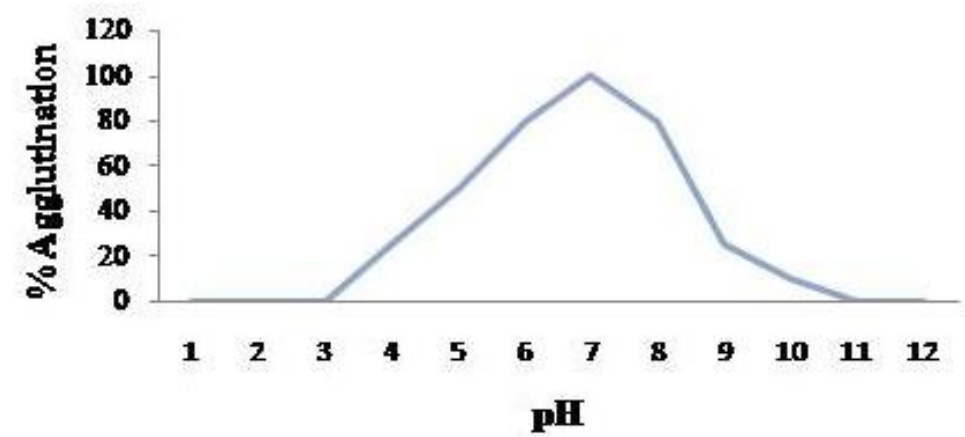

Figure 2. Effect of pH on Agglutination activity of lectin of Euphorbia tithymaloides leaves.

Effect of temperature and thermal inactivation

Lectin from leaves of ET shows $100 \%$ agglutination between temperatures ranging from $40-60^{\circ} \mathrm{C}$ when tested after heated for $1 \mathrm{~h}$ at temperature above $20^{\circ} \mathrm{C}$. Below $40^{\circ} \mathrm{C}$ and above $60^{\circ} \mathrm{C}$ till $70^{\circ} \mathrm{C}$ agglutination activity was half of initial and as the temperature increases the activity decreases and finally lost at $100^{\circ} \mathrm{C}$. According to the observed result lectin was stable for long period of time but it thermally inactive after heating at $100^{\circ} \mathrm{C}$ as showed in figure 3.

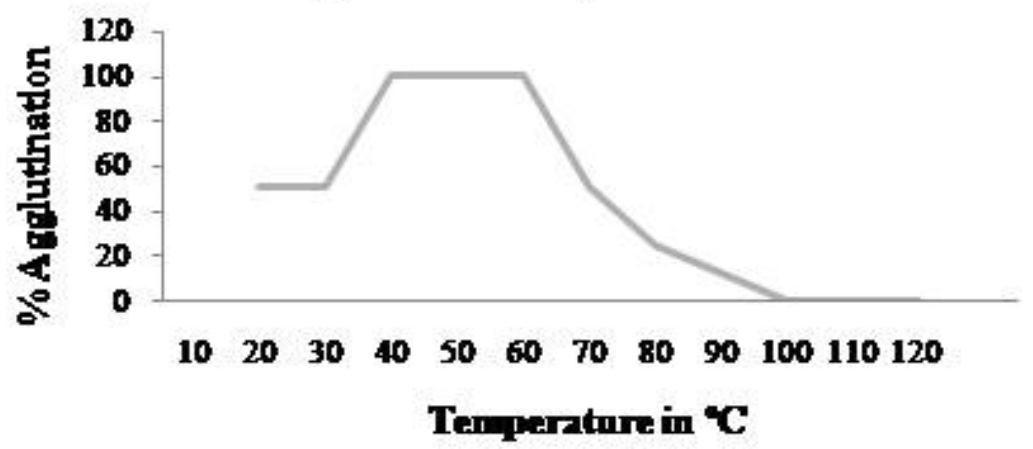

Figure 3. Effect of temperature on Agglutination activity of lectin of Euphorbia tithymaloides leaves. www.tropicalplantresearch.com 
1D-SDS polyacrylamide gel electrophoresis

SDS-PAGE resulted into the appearance of bands with molecular weight of 70.24, 28.53 and $14.68 \mathrm{kDa}$ in the purified extract from leaves of ET showed in figure 4. Thus, these may be the molecular mass of lectins present in ET.

\section{Lane 1}

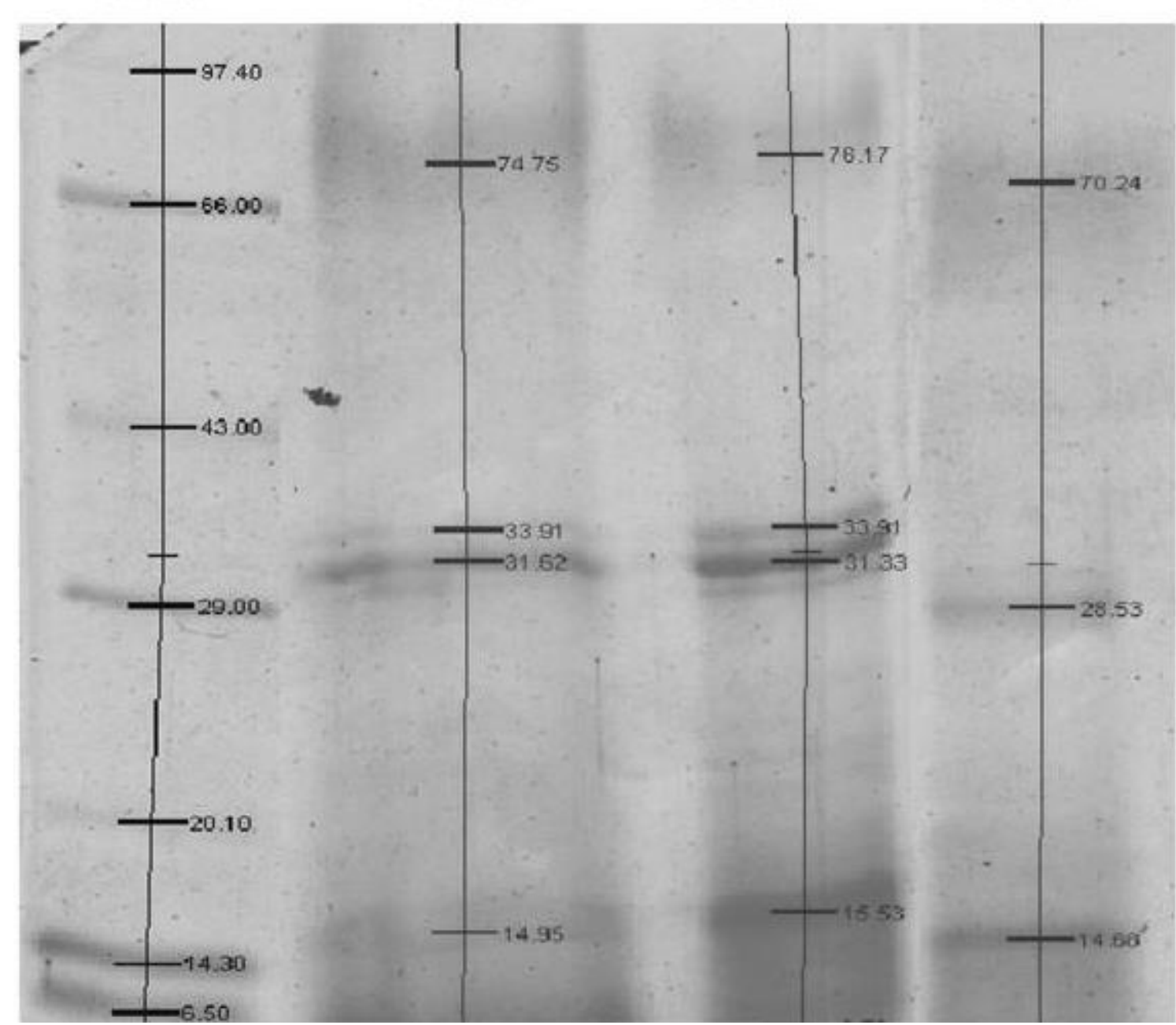

Figure 4. Band pattern of lectins of ET on 1-D SDS-PAGE
Lane 2
Lane 3

Lane 4

2D-SDS polyacrylamide gel electrophoresis

On the basis of analyses of 12 observed spots, which were ranging in between pIs of 6.5 to 29 as showed in the figure 5 .

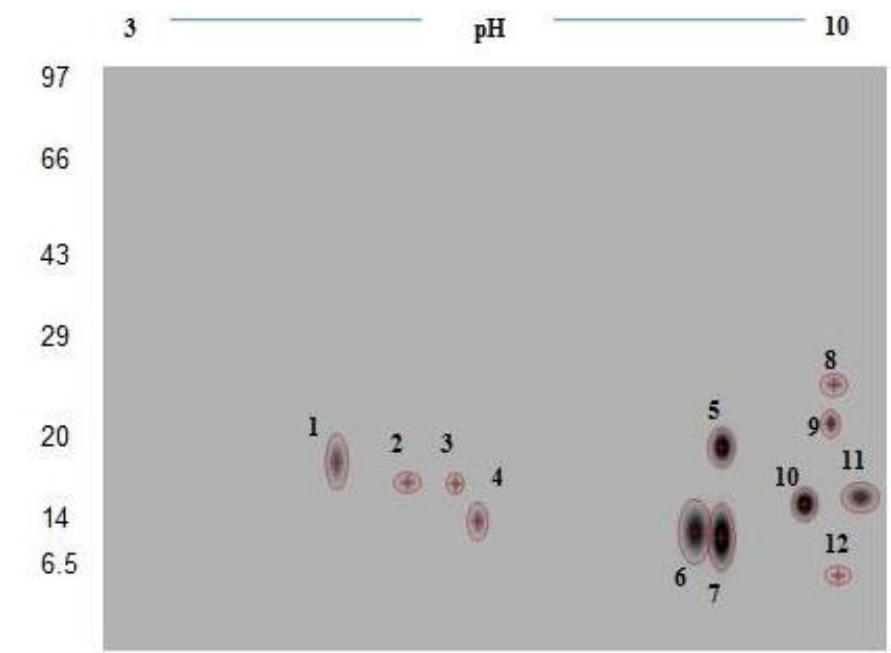

Figure 5. Isoelectric focusing of lectins of ET on 2-D PAGE 


\section{DISCUSSION}

This study focused on identification and characterization of the lectin activities from ET plant species. Lectins were extracted and purified by using conventionalammonium sulfate precipitation method. The purification procedure consists of 0-100\% ammonium sulfate saturation, which was followed by dialysis. The conventional ammonium sulfate precipitation method was very useful technique for initial purification of lectins from crude extract of Tridax procumben leaves (Ramteke \& Patil 2005) and Volvariella volvacea (Mothong 2009).

The extract agglutinates the erythrocytes of ABO blood group which resembles the characteristics of most of the glycoproteins. Nagata \& Burger (1974) had reported that wheat germ lectins (WGL) were non blood group specific lectins. The present study also convinced with the above report as lectins of ET agglutinated RBC of all blood groups with similar competence indicating that there is no specificity towards blood groups. This may be due to absence of lectins specific receptors on the surface of RBSs. Lectins of many plant species also agglutinate with erythrocytes of different animals. Ramteke \& Patil (2005) noted that lectin of Tridax procumbans agglutinates dog erythrocyte. Similar results were also observed in case of lectins of ET which can be also supported by the study of Ahmed \& Chatterjee (1987).

Lectins have the specific ability to bind carbohydrates which was examined by hemagglutination inhibition assay. Goldstein \& Hayes (1978) has reported that the lectins of Euphorbiaceae family are galactose specific. In the same line Irazoqui et al. (2005) and Lubaki et al. (1983) noted that E. miliiand, E. heterophylla species are galactose specific lectins. Our findings are also on the same line as lectins of ET were inhibited by D-galactose and lactose which shows galactose specificity. Similar inhibition was observed in Tridax procumbens (Ramteke \& Patil 2005), tubers of Dioscorea opposite (Chan \& Ng 2013) and Zizyphus oenoplia (Butle \& Patil 2015).

Optimum $\mathrm{pH}$ for maximum activity of lectins varies in different plant species. In present study lectins of ET shows optimum activity at neutral pH-7 and at the same time it is inactive at extreme acidic and basic $\mathrm{pH}$. Similar activity had been observed in many species like Spatholobus parviflorus (Geethanandan 2010), Volvariella volvacea lectins (Mothong 2009), bioactive lectin from Zizyphus oenoplia (Butle \& Patil 2015), calyx lectin of Tridax procumbens (Ramteke et al. 2005), Apios tuber lectin (Kenmochi et al. 2015) and Jackfruit (Artocarpus integrifolia) lectin (Ahmed \& Chatterjee 1987).

Thermal stability of lectins was studied in ET shows maximum activity at temperature range from $40-60^{\circ} \mathrm{C}$ respectively and loses its activity at $100^{\circ} \mathrm{C}$. Similar results were observed in case of Jackfruit (Artocarpus integrifolia) lectins (Ahmed \& Chatterjee 1987) and Apios tuber lectin (Kenmochi et al. 2015) in which the activity was lost after $85^{\circ} \mathrm{C}$. Geethanandan (2010) and Pereira et al. (2015) mentioned that lectins of Spatholobus parviflorus and Colocasia esculenta respectively, lose their activity after $100^{\circ} \mathrm{C}$.

The purified lectins from ET were processed on One Dimensional SDS-PAGE to get molecular mass as shown in figure 4. Lectins with molecular mass 70.24, 28.53 and $14.68 \mathrm{kDa}$ were obtained. MW of lectin present in E. heterophylla (Lubaki et al. 1983) resembles with the result as it also possesses dimeric protein with two identical subunits of $32 \mathrm{kDa}$. Thus, it may be possible that ET have subunits of 33.91 and $31.33 \mathrm{kDa}$.

Two dimensional SDS-PAGE isoelectric points (pI) of ET were obtained as shown in figure 5. According to Pereira et al. (2015) in Colocasia esculenta16 spots with pIs ranging from 6.5 to 9.5 were reported. Similarly, in our study 12 spots with pIs ranging from 6.5 to 29 were obtained. Similar results were also obtained in Volvariella volvacea (Mothong 2009) and Cyphomandra betacea (Xu 1991).

\section{CONCLUSION}

Partial purified ET plants lectins exhibited strong agglutination with erythrocytes of different species however, the titer against $\mathrm{O} R \mathrm{Rh}+$ was higher than $\mathrm{B} \mathrm{Rh}+$ and $\mathrm{A} \mathrm{Rh}+$ and cow. In contrast, no haem agglutination of goat, dog and fish erythrocyte was observed. Result would be explained by differences in glycosylation of the surface protein in different species of erythrocytes. Agglutination activity of ET was completely inhibited by Galactose and lactose sugars it exhibited that lectins of ET are galactose specific.

Plant lectins showed optimum activity at different $\mathrm{pH}$ and temperature range. Extreme acidic and basic $\mathrm{pH}$ inhibits the lectin activity of ET whereas at neutral $\mathrm{pH}$ gives optimum activity. ET lectins works between temperatures range $40-60{ }^{\circ} \mathrm{C}$ and gradually loses its activity at higher temperature and completely loss after $100^{\circ} \mathrm{C}$. It indicated that this lectin is not thermostable. Based on one dimensional study, bands with molecular mass $70.24,28.53$ and $14.68 \mathrm{kDa}$ were expressed in purified lectins samples. Galactose specific lectins isolated 
from other plants have been reported to be dimeric or tetremeric proteins. Thus, it may be possible that ET have subunits of 33.91 and $31.33 \mathrm{kDa}$.

From the literature surveys and reports it can be said that the importance of lectin is widely spread in cellular and molecular biology. There are several applications of lectins including treatment of various diseases, as a potential therapeutic agent and lectins also act as markers. The role of lectins in research has been steadily increasing these days. There are many unidentified flora lectins. So, those plants should be explored for experimental investigation to make lectins next generation's medicine and food.

\section{ACKNOWLEDGEMENTS}

Authors are thankful to Director of National Institute of Miners' Health for their valuable support and encouragement. We are also grateful to local people for their help during the field study.

\section{REFERENCES}

Abreu P \& Matthew S (2006) Anti-inflammatory and antioxidant activity of a medicinal tincture from Pedilanthusti thymaloides. Life Sciences 78: 1578-1585.

Ahmed H \& Chatterjee BP (1987) Further Characterization and Immuno chemical Studies on the Carbohydrate Specificity of Jackfruit (Artocarpus integrifolia) lectin. The Journal of Biological Chemistry 264(16): 93659372.

Ajit CG \& Kanjaksha G (2016) Use of lectins in immunohematology. Asian Journal of Transfusion Science 10(1): 12-21.

Butle AB \& Patil MB (2015) Isolation and characterization of a bio reactive lectin from Zizyphus oenoplia. World Journal of Pharmaceutical Sciences 3(7): 1413-1420.

Chan YS \& Ng TB (2013) A lectin with highly potent inhibitory activity toward breast cancer cells from edible tubers of Dioscorea opposite cv. Nagaimo. Plos one 8(1): e54212: 1-11.

Deshpande K \& Patil M (2003) Studies of lectins of wild medicinal plant, Ph.D. Thesis. Nagpur University, Nagpur, Maharashtra, India.

Geethanandan K (2010) Isolation, purification and crystal structure analysis of a new lectin from Spatholobus parviflorus, Ph.D. Thesis. Kannur University, Kerela, India.

Goldstein IJ \& Hayes CE (1978) The lectins: carbohydrate-binding proteins of plants and animals. Advances in Carbohydrate Chemistry and Biochemistry 35: 127-340.

Irazoqui FJ, Hamp MMV, Lardone RD, Villarreal MA, Sendra VG, Montich GG, Trindade VM, Clausen H \& Nores GA (2005) Fine carbohydrate reconition of Euphorbia milii lectins. Biochemical and biophysical research communications 336: 14-21.

Kenmochi E, Kabir SR, Ogawa T, Naude R, Tateno H \& Hirabayashi J (2015) Isolation and biochemical characterization of Apios tuber lectin. Molecules 20: 987-1002.

Kurokawa T, Tsuda M \& Sugino Y (1976). Purification and characterization of lectin from Wistaria floribunda seeds. The Journal of Biological Chemistry 251: 5686-5693.

Lubaki MN, Peumans WJ \& Carlier AR (1983) Isolation and partial characterization of a lectin from Euphorbia heterophylla seeds. Biochemical Journal 215: 141-145.

Mothong N (2009) Lectins from straw mushroom cultivated in north-eastern Thailand, Ph.D. Thesis. Suranaree University of technology, Nakhon Ratchasima, Thailand.

Nagata Y \& Burger MM (1974) Wheat Germ Agglutinin: Molecular characteristics and specificity for sugar binding. The Journal of Biological Chemistry 249: 3116-3122.

Olsen ID (1944) The use of lectins (Agglutinins) to study cell surface, Ph.D. Thesis. Columbia University, New York City, USA.

Patil MB \& Deshpande KV (2015) Isolation and characterization of lectin from leaves of Dregea volubilis. Journal of Global Biosciences 4: 2496-2503.

Pereira PR, Winter HC, Vericimo MA, Meagher JL, Stuckey JA, Goldstein IJ, Paschoalin VMF \& Silva JT (2015) Structural analysis and binding properties of isoform of tarin, the GNA-related lectin from Colocasia esculenta. Biochimica et Biophysica Acta 1854(1): 20-30.

Peumans WJ \& Damme EJMV (1998) Plant lectins: Versatile proteins with important perspectives in biotechnology. Biotechnology and Genetic Engineering Reviews 15: 199-228. 
Ramteke AP \& Patil MB (2005) Purification and characterization of Tridax procumbens calyx lectin. Biosciences Biotechnology Research Asia 3: 103-110.

Ramteke AP (2009) Studies on the lectins of some medicinal plants, Ph.D. Thesis. Nagpur University, Nagpur, Maharashtra, India.

Sharon N \& Lis H (2004) History of lectins: from hemagglutinins to biological recognition molecules. Glycobiology 14: 53-62.

Suseelan KN, Bhatia CR \& Mitra R (1997) Purification \& characterization of twomajorlectins from Vignamungo. Journal of Biosciences 22 (4): 439-455.

Weber K \& Osborne M (1969) The reliability of molecular weight determination by sodium dodecyl sulphatepolyacryl amide gel electrophoresis. The Journal of Biochemistry 244: 4406-4412.

Xu C (1991) Purification and characterization of a lectin from tamarillo fruits (Cyphomandra betacea), Ph.D. Thesis. Massey University Library, Palmerston North, New Zealand. 